\title{
Measurement of inflammatory indices in induced sputum: effects of selection of sputum to minimize salivary contamination
}

\author{
E. Pizzichini, M.M.M. Pizzichini, A. Efthimiadis, F.E. Hargreave, J. Dolovich
}

\begin{abstract}
Measurement of inflammatory indices in induced sputum: effects of selection of sputum to minimize salivary contamination. E. Pizzichini, M.M.M. Pizzichini, A. Efthimiadis, F.E. Hargreave, J. Dolovich. CERS Journals Ltd 1996.

ABSTRACT: Sputum examination is being used increasingly as a noninvasive method to assess airway inflammation. Expectorated sputum has variable contamination with saliva. Methods of processing have included the selection of portions of the sample considered to be representative of pulmonary origin versus use of the whole specimen, which is confounded by varying volumes of saliva. We compared cell profiles and eosinophilic cationic protein (ECP) concentration in sputum selected from the expectorate and in the usually discarded residual portion to determine to what degree salivary contamination is minimized and if the results are representative of lower respiratory secretions.

Sputum was induced with hypertonic saline in six healthy and nine asthmatic subjects. All portions considered to be of pure lower respiratory tract origin were selected from the residual. The selected and residual portions were treated with dithiothreitol, total cell counts and cell viability were obtained, cytospins were made for differential cell counts and supernatant was collected for ECP assay.

Selected portions of the specimens, in comparison with the residual portion showed: little squamous cell contamination (median 1.2 vs $70 \% ; \mathrm{p}<0.001$ ); higher total cell counts'mL $\mathrm{mL}^{-1}\left(5.1\right.$ vs $0.5 \times 10^{6}$ cells $\left.\cdot \mathrm{mL}^{-1} ; \mathrm{p}<0.001\right)$; higher number of viable nonsquamous cells per sample $\left(1.9\right.$ vs $0.6 \times 10^{6}$ cells; $\left.p<0.001\right)$; higher slide quality score (7 vs 4; p $<0.001)$; and higher levels of ECP (768 vs $\left.136 \mu \mathrm{g} \cdot \mathrm{L}^{-1} ; \mathrm{p}<0.001\right)$. There were no differences in the differential cell counts of eosinophils $(1.3 v s 3.8 \%)$, neutrophils $(44 v s 32 \%)$, and lymphocytes $(0.6$ vs $0.6 \%)$. While the proportion of macrophages was lower (36 vs 54\%; p $<0.05)$, the absolute number (41 vs $19 \times 10^{4}$ cells; $\mathbf{p}<\mathbf{0 . 0 5}$ ) was higher in the selected portion.

In summary, selection of all portions of induced sputum from the expectorate minimized the confounding influence of saliva. Loss of nonsquamous cells in the residual portion was variable but usually less than one third of those in the selected portion. With one exception, this loss had little influence on the differential counts of inflammatory cells. Similar observations apply to eosinophilic cationic protein levels. We conclude that, in healthy subjects and treated asthmatics, inflammatory markers in the selected portion of the expectorate can be used to represent those in the lower respiratory tract in general.
\end{abstract}

Eur Respir J., 1996, 9, 1174-1180.

Asthma Research Group, Departments of Medicine and Paediatrics, St. Joseph's Hospital and McMaster University, Hamilton, Ontario, Canada.

Correspondence: J. Dolovich

McMaster University

Faculty of Health Sciences

1200 Main Street West

Hamilton, Ontario

Canada

L8N 5 Z5.

Keywords: Asthma

sputum cell counts

sputum eosinophilic cationic protein

sputum induction

Received: June 131995

Accepted after revision February 21996

Supported by grants from the Father Sean O'Sullivan Research Centre, Astra Pharmaceutical Inc. and Boehringer Ingelheim (Canada) Ltd. E.P. and M.M.M.P. were supported by a Fellowship from CAPES, Ministry of Education, Brazil.
A better understanding of airway diseases and their treatment requires examination of indices of the airway inflammation which is considered to be their cause [1]. Examination of spontaneous or induced sputum promises to be a reliable direct method by which this can be achieved noninvasively [2-8].

Sputum, which is defined as expectorated lower respiratory secretions [9], is composed of fluid and cellular components, including macrophages, bronchial epithelial cells and inflammatory cells. When it is expectorated, it becomes mixed with saliva composed chiefly of fluid, squamous epithelial cells and oropharyngeal bacteria. In evaluating the examination of sputum for indices of airway inflammation, we have examined sputum selected from the expectorate $[2,3,7]$, whilst others have used the full expectorant of sputum plus saliva [5]. The selection process is not difficult and should reduce the confounding influence of saliva. The more viscid portions, considered to be sputum, are usually easy to recognize macroscopically when the sample is poured into a Petri dish. Occasionally, when the sample is homogeneous, we have used phase contrast microscopy to help select the nonsquamous cellular portion from that composed of a large quantity of squamous epithelial cells derived from saliva.

The selection of uncontaminated sputum from the expectorate is supported by studies using sputum to investigate lung cancer and lower respiratory infection. In cancer investigation, expectorated samples contaminated with higher concentrations of squamous epithelial cells give more false negative results [10]. In microbiological 
studies, samples with low salivary contamination (less than $25 \%$ squamous epithelial cells) yield fewer species of cultured bacteria, indicating less contamination, and compare more closely with transtracheal aspirates [11, 12]. In the investigation of indices of airway inflammation, however, the effects of selecting sputum from the expectorate have not been studied. Potential advantages are that the denominator of the source of indices measured, i.e. the weight or volume of sputum is known. A possible disadvantage is that data might be lost if the selection is inadequate, particularly if the sputum is in-homogeneous.

In the present study, the cell profiles and eosinophilic cationic protein (ECP) concentrations were compared in selected and residual portions of the expectorate, to determine the success of minimizing salivary contamination in the selected portion and to investigate to what degree the results were representative of lower respiratory secretions. Sputum was induced in 15 healthy or asthmatic subjects and the two portions were examined blind for the percentage of squamous cell admixture, quality of cell preparation on slides, total cell count per millilitre of sample, absolute number of cells, cell viability, differential cell count and a representative measurement of inflammatory markers in the fluid phase, ECP concentration.

\section{Subjects and methods}

\section{Subjects}

Six healthy and nine asthmatic nonsmoking adults attending the clinics of the Firestone Regional Chest and Allergy Unit volunteered to participate in the study. The healthy subjects had no history of respiratory disease, a forced expiratory volume in one second as a percentage of vital capacity $(\mathrm{FEV} 1 / \mathrm{VC})>80 \%$, and normal methacholine airway responsiveness (provocative concentration of methacholine causing a $20 \%$ fall in FEV1(PC20) $\left.>16 \mathrm{mg} \cdot \mathrm{mL}^{-1}\right)$. Asthmatics had a history of asthma symptoms or a previous physician diagnosis. The asthma was objectively confirmed in eight subjects, who had a FEV1/ $\mathrm{VC} \geq 70 \%$, by methacholine airway hyperresponsiveness $\left(\mathrm{PC} 20<8 \mathrm{mg} \cdot \mathrm{mL}^{-1}\right)$, and in one subject, who had a FEV1/ $\mathrm{VC}<70 \%$, by an improvement in FEV $1>20 \%$ after salbutamol $(200 \mu \mathrm{g})($ table 1$)$. The study was approved by the research committee of St. Joseph's Hospital and written informed consent was obtained.
Methods

\section{Sputum induction}

Sputum was induced with an aerosol of inhaled hypertonic saline using a modification of the method of PIN et al. [3] after pretreatment with inhaled salbutamol 200 $\mu \mathrm{g}$. The modification consisted of inhaling the hypertonic saline in concentrations of 3,4 and 5\% each for 7 min. Subjects were instructed to rinse the mouth with water and blow the nose after each inhalation to avoid contamination with saliva and postnasal drip. The sample was collected in a sterile container and was examined as soon as possible, within $2 \mathrm{~h}$.

\section{Sputum examination}

The whole sample of sputum and saliva was transferred to a Petri dish, and the weight and macroscopic characteristics of the sample were recorded. All portions that macroscopically appeared free of salivary contamination (selected portion) were placed in a preweighed $15 \mathrm{~mL}$ polystyrene tube. For two specimens, where there was a homogeneous mixture of sputum and saliva, selection was made with an inverted microscope to obtain a cellular sample with as small a number of squamous epithelial cells as possible. The weight of the selected portion was recorded. The residual portion was placed in a $50 \mathrm{~mL}$ polystyrene conical tube and the volume recorded. Both portions were treated with fresh dithiothreitol (DTT) in a balanced salt solution (Sputolysin 10\%; Calbiochem Corp., San Diego, CA, USA) diluted to $0.1 \%$ by the addition of distilled water. The selected portion was treated with a volume of DTT of four times the weight, while the residual portion was diluted by an equal volume of DTT. The portions were agitated in a vortex mixer for $15 \mathrm{~s}$, and gently aspirated in and out of a pipette to ensure mixing. The polystyrene tubes were then placed in a bench rocker (Dade Tube Rocker; Baxter Diagnostics Corp., Miami, USA) and rocked for $15 \mathrm{~min}$. A further four volumes of Dubelcco's phosphate-buffered saline (DPBS) was added to the selected portion, giving a final concentration of $0.05 \%$ DTT in the solution, and was rocked for a further $5 \mathrm{~min}$. For example, if the sample

Table 1. - Characteristics of asthmatic subjects

\begin{tabular}{|c|c|c|c|c|c|c|c|}
\hline $\begin{array}{l}\text { Subject. } \\
\text { No. }\end{array}$ & $\begin{array}{l}\text { Age } \\
\text { yrs }\end{array}$ & Sex & $\begin{array}{l}\mathrm{FEV} 1^{*} \\
\% \text { pred }\end{array}$ & $\begin{array}{c}\mathrm{FEV}_{1} / \mathrm{VC} \\
\% \\
\end{array}$ & $\begin{array}{c}\mathrm{PC} 20 \\
\mathrm{mg} / \mathrm{mL}\end{array}$ & Sputum & $\begin{array}{l}\text { Treatment } \\
\text { Eos } \%\end{array}$ \\
\hline 1 & 23 & $\mathrm{~F}$ & 65 & 69 & ND & 72.1 & IS $2400, \mathrm{P}, \mathrm{T}, \mathrm{B}$ \\
\hline 2 & 54 & M & 67 & 70 & 2.0 & 27.3 & B \\
\hline 3 & 21 & $\mathrm{~F}$ & 83 & 83 & 1.1 & 15.2 & IS $2250, \mathrm{~B}$ \\
\hline 4 & 20 & M & 75 & 78 & 3.7 & 5.0 & IS 200, B \\
\hline 5 & 23 & $\mathrm{~F}$ & 87 & 78 & 4.3 & 1.3 & B \\
\hline 6 & 23 & $\mathrm{~F}$ & 89 & 77 & 4.3 & 1.0 & Nil \\
\hline 7 & 63 & M & 78 & 74 & 2.8 & 0.7 & Nil \\
\hline 8 & 28 & $\mathrm{~F}$ & 92 & 81 & 0.9 & 0.6 & IS $1000, \mathrm{~B}$ \\
\hline 9 & 65 & $\mathrm{~F}$ & 82 & 70 & 0.2 & 0.4 & IS $1000, \mathrm{~B}$ \\
\hline
\end{tabular}

*: before beta-agonist. Predicted FEV1 from CRAPO et al. [13]. M: male; F: female; FEV1: forced expiratory volume in one second; \% pred: percentage of predicted value; VC: vital capacity; PC20: provocation concentration of methacholine to cause a $20 \%$ fall in FEV1 (normal >16 mg. $\mathrm{mL}^{-1}$ [14]); Eos: eosinophils; ND: not determined; IS: inhaled steroids (beclamethasone dipropionate or budesonide (dose in $\left.\mathrm{mg}^{-} \mathrm{day}^{-1}\right)$ ); P: prednisone; T: theophylline; B: inhaled beta-agonist. 
weighed $500 \mathrm{mg}, 2,000 \mu \mathrm{L}$ of DTT were added initially, followed $15 \mathrm{~min}$ later by $2,000 \mu \mathrm{L}$ of DPBS, to give a final dilution of about eight times the sample weight. Because the volume of the residual portion was already large, it was not diluted further but was also rocked for 5 min more. The suspensions were then filtered through $48 \mu \mathrm{m}$ nylon gauze (B \& SH Thompson, Scarborough, Ontario, Canada); which does not result in selected cell loss [15], to remove cell debris and mucus. The resulting suspension was spun at $790 \times \mathrm{g}$ for $10 \mathrm{~min}$ and the supernatant was aspirated and stored in Eppendorf tubes at $-70^{\circ} \mathrm{C}$ for later analysis.

The pellet was resuspended in a volume of 200-600 $\mu \mathrm{L}$ of DPBS, depending on macroscopic size, to obtain a total cell count in a Neubauer haemocytometer. The viability of nonsquamous cells in the selected and residual portions was evaluated by the trypan blue exclusion method, the blue cells being considered dead. The total number of cells per millilitre of processed sputum was calculated for both portions, as well as the absolute number of nonsquamous and live cells in each portion (absolute total cell count per portion minus the squamous and dead cell counts). The cell suspension was then adjusted to $1.0 \times 10^{6}$ cells $\cdot \mathrm{mL}^{-1}$ and $75 \mu \mathrm{L}$ of cell suspension and placed into the cups of a Shandon III cytocentrifuge (Shandon Southern Instruments, Sewickley, PA, USA). Two coded cytospins were prepared at $450 \mathrm{rpm}$ for 6 min. The slides were air-dried and stained using Wright stain. Four hundred nonsquamous cells were counted in the selected portion and, because of the high amount of squamous cell contamination, only 200 cells were counted in the residual portion. The nonsquamous differential cell count was expressed as a percentage of the total nonsquamous count. A score of the quality of the cell preparation on the slide was determined by another technician blind to details of the cell counts. The score varied from a minimum of 3 to a maximum of 9 based on: cell debris (nil $=3$; moderate $=2$; and excessive $=1$ ); cell outline (preserved $=3$; isolated cell damage $=2$; and most cells damaged $=1$ ); and overall impression (good $=3$; acceptable $=2$; and bad=1). An effort was made to count all cytospins, even if they did not meet our criteria for ideally countable cytospins (squamous epithelial cells $<20 \%$, cell viability $>50 \%$, and slide quality score $>4$ ).

The ECP concentration of the thawed supernatant was determined by radioimmunoassay (RIA), (Kabi Pharmacia Diagnostics AB, Uppsala, Sweden). The results were adjusted for the dilution factor and the concentration expressed in $\mu \mathrm{g} \cdot \mathrm{L}^{-1}$.

\section{Effect of DTT on ECP assay}

To examine the effect of DTT on ECP measurements, a standard curve with DTT was made and compared with the curve with normal saline. With DTT added to the reference protein the standard curve retained the shape of the standard curve without DTT, but the individual plots on the graph were about two percentage points lower.

\section{Statistical analysis}

The data are expressed as the median with maximum and minimum values unless otherwise specified. Differences between selected and residual portions were assessed by the two-tailed paired t-test. Variables with nonnormal distribution were log or square-root transformed before analysis, when indicated [16]. Nonparametric statistics (McNamer test) were used to compare countable cytospins. Spearman signed rank coefficient $\left(r_{s}\right)$ was used to examine the relationship between proportions of eosinophils in sputum and ECP concentrations in the fluid phase [17]. Significance was accepted at the $95 \%$ level.

\section{Results}

The median (range) weight of expectorated specimens was $6.8(1.05-16.13) \mathrm{g}$ and their appearance was mucoid.

Table 2. - General characteristics of selected (S) and residual (R) portions of expectorate

\begin{tabular}{|c|c|c|c|c|c|c|c|c|c|c|}
\hline \multirow{2}{*}{$\begin{array}{l}\text { Subject } \\
\text { No. }\end{array}$} & \multicolumn{2}{|c|}{$\begin{array}{l}\text { Weight } \\
\text { mg }\end{array}$} & \multicolumn{2}{|c|}{$\begin{array}{c}\text { Viability } \\
\%\end{array}$} & \multicolumn{2}{|c|}{$\begin{array}{c}\text { Squamous cells } \\
\%\end{array}$} & \multicolumn{2}{|c|}{$\begin{array}{l}\text { Total cell count } \\
\quad \times 10^{6} \cdot \mathrm{mL}^{-1}\end{array}$} & \multicolumn{2}{|c|}{$\begin{array}{l}\text { Absolute number of } \\
\text { nonsquamous, viable } \\
\text { cells } \times 10^{3}\end{array}$} \\
\hline & $S$ & $\mathrm{R}$ & S & $\mathrm{R}$ & $S$ & $\mathrm{R}$ & $S$ & $\mathrm{R}$ & S & $\mathrm{R}$ \\
\hline 1 & 321 & 9000 & 15 & 10 & 0.0 & 95 & 3.5 & 0.4 & 173 & 18 \\
\hline 2 & 479 & 2000 & 86 & 83 & 1.2 & 86 & 1.4 & 0.3 & 570 & 77 \\
\hline 3 & 549 & 1790 & 85 & 64 & 0.0 & 73 & 4.7 & 0.2 & 2189 & 50 \\
\hline 4 & 332 & 715 & 37 & 35 & 5.8 & 61 & 2.4 & 0.9 & 281 & 90 \\
\hline 5 & 485 & 3500 & 87 & 71 & 0.0 & 49 & 7.1 & 0.5 & 2965 & 610 \\
\hline 6 & 437 & 5000 & 95 & 74 & 0.0 & 14 & 4.9 & 0.6 & 2048 & 1814 \\
\hline 7 & 440 & 8800 & 76 & 52 & 0.3 & 59 & 5.1 & 0.5 & 1686 & 899 \\
\hline 8 & 300 & 6500 & 94 & 93 & 0.8 & 71 & 10.9 & 0.7 & 3049 & 1196 \\
\hline 9 & 480 & 6000 & 89 & 63 & 1.3 & 69 & 5.1 & 0.6 & 2167 & 732 \\
\hline 10 & 280 & 11000 & 90 & 88 & 0.7 & 94 & 3.8 & 0.2 & 951 & 83 \\
\hline 11 & 210 & 14200 & 81 & 56 & 1.3 & 94 & 3.1 & 0.2 & 522 & 66 \\
\hline 12 & 636 & 7500 & 75 & 20 & 7.9 & 62 & 6.2 & 1.1 & 2724 & 616 \\
\hline 13 & 363 & 7800 & 86 & 20 & 6.0 & 70 & 10.2 & 1.3 & 2993 & 589 \\
\hline 14 & 665 & 5500 & 84 & 69 & 3.3 & 24 & 1.6 & 0.4 & 864 & 1039 \\
\hline 15 & 126 & 16000 & 86 & 13 & 3.2 & 97 & 17.8 & 0.2 & 1867 & 8 \\
\hline Median & 437 & 6500 & 86 & 63 & 1.2 & 70 & 5.1 & 0.5 & 1867 & 589 \\
\hline
\end{tabular}


The selected portion accounted for $6.4(0.8-32) \%$ of the whole sample and, in comparison with the residual portion, contained: little squamous epithelial cell (salivary) contamination; higher total cell counts; a higher number of viable nonsquamous cells (table 2); and a higher slide quality score of $7(6-9)$ vs $4(3-8) \mathrm{p}<0.001$. As a result, $93 \%$ of cytospins from the selected portion were defined as ideally countable compared with only $33 \%$ from the residual portion $(\mathrm{p}<0.001)$

Differential cell counts on cytospins could be obtained in all 15 selected portions but in only 12 residual portions, because of a low quality of slide score associated either with high squamous cell contamination or low cell viability (table 3 ). In the counted cytospins, the differential cell counts were similar between selected and residual portions for eosinophils, neutrophils and lymphocytes but macrophages were higher in the residual portion. The absolute number $\left(\times 10^{4}\right)$ of viable eosinophils (3.0 vs 0.9$)$, neutrophils (68 vs 15), lymphocytes (0.9 vs 0.2$)$ and macrophages $(41$ vs 19) were significantly higher $(\mathrm{p}<0.05)$ in the selected portion.

The ECP concentration was always higher in the fluid phase from the selected portion, the mean being 5.6 times higher $(\mathrm{p}<0.001)$ (table 4 and fig. 1). The ratio between the ECP concentration in the selected and residual portions was not uniform, varying between 1.3 and 37.3 times. There was a positive correlation between the proportion of eosinophils and the concentrations of ECP both in selected $\left(r_{s}=0.75 ; p=0.001\right)$ and residual portions $\left(r_{s}=0.74\right.$; $\mathrm{p}=0.006$ ).

Table 3. - Differential cell count (\%) in selected (S) and residual (R) portions of expectorate

\begin{tabular}{|c|c|c|c|c|c|c|c|c|}
\hline \multirow{2}{*}{$\begin{array}{l}\text { Subject } \\
\text { No. }\end{array}$} & \multicolumn{2}{|c|}{ Eosinophils \% } & \multirow{2}{*}{$\begin{array}{l}\text { Neutrophils } \\
\text { S }\end{array}$} & \multirow{2}{*}{$\begin{array}{l}\% \\
\mathrm{R}\end{array}$} & \multirow{2}{*}{$\begin{array}{l}\text { Macrophages } \\
\text { S }\end{array}$} & \multirow{2}{*}{$\begin{array}{l}\% \\
\mathrm{R}\end{array}$} & \multirow{2}{*}{$\begin{array}{l}\text { Lymphocytes } \\
\text { S }\end{array}$} & \multirow{2}{*}{$\begin{array}{l}\% \\
\mathrm{R}\end{array}$} \\
\hline & S & $\mathrm{R}$ & & & & & & \\
\hline 1 & 27.3 & 7.3 & 49 & 56 & 23 & 36 & 0.5 & 0.5 \\
\hline 2 & 0.4 & 0.5 & 7 & 8 & 88 & 90 & 3.2 & 1.5 \\
\hline 3 & 5.0 & 10.5 & 49 & 38 & 46 & 45 & 0.4 & 3.8 \\
\hline 4 & 15.2 & 8.5 & 4 & 6 & 80 & 83 & 0.5 & 0.7 \\
\hline 5 & 0.7 & 5.0 & 38 & 21 & 61 & 73 & 0.2 & 1.0 \\
\hline 6 & 0.6 & 1.0 & 83 & 75 & 16 & 24 & 0.4 & 0.3 \\
\hline 7 & 1.0 & 0.5 & 93 & 82 & 6 & 17 & 0 & 0.5 \\
\hline 8 & 1.3 & 2.5 & 80 & 74 & 17 & 24 & 0.7 & 0 \\
\hline 9 & 72.1 & 42.0 & 8 & 25 & 13 & 33 & 2.3 & 0.7 \\
\hline 10 & 2.0 & 5.0 & 13 & 6 & 83 & 88 & 1.0 & 0.1 \\
\hline 11 & 0.3 & ND & 11 & ND & 86 & ND & 0.7 & ND \\
\hline 12 & 1.9 & ND & 34 & ND & 64 & ND & 0.5 & ND \\
\hline 13 & 1.3 & 2.5 & 25 & 33 & 69 & 64 & 0.8 & 0.3 \\
\hline 14 & 0.2 & 1.0 & 72 & 31 & 27 & 65 & 0.9 & 1.0 \\
\hline 15 & 0.2 & ND & 24 & ND & 71 & ND & 1.0 & ND \\
\hline Median & 1.3 & 3.8 & 44 & 32 & 36 & 54 & 0.6 & 0.6 \\
\hline
\end{tabular}

ND: not determined due to low quality of slide score. Median values were calculated from all subjects except subjects Nos 11 , 12 and 15 .

Table 4. - ECP concentrations and ratios in selected $(\mathrm{S})$ and residual $(\mathrm{R})$ portions of expectorate

\begin{tabular}{|c|c|c|c|}
\hline \multirow{2}{*}{$\begin{array}{l}\text { Subject } \\
\text { No. }\end{array}$} & \multicolumn{2}{|c|}{$\begin{array}{l}\text { ECP } \\
\mu \mathrm{g} \cdot \mathrm{L}-1\end{array}$} & \multirow{2}{*}{$\begin{array}{c}\mathrm{ECP} \\
\text { ratio } \\
\mathrm{S} / \mathrm{R}\end{array}$} \\
\hline & $\mathrm{S}$ & $\mathrm{R}$ & \\
\hline 1 & 6000 & 184 & 32.6 \\
\hline 2 & 96 & 15 & 6.3 \\
\hline 3 & 2040 & 136 & 15.0 \\
\hline 4 & 3440 & 280 & 12.2 \\
\hline 5 & 920 & 220 & 4.2 \\
\hline 6 & 224 & 176 & 1.3 \\
\hline 7 & 472 & 184 & 2.6 \\
\hline 8 & 1040 & 128 & 8.1 \\
\hline 9 & 696 & 100 & 6.96 \\
\hline 10 & 336 & 9 & 37.3 \\
\hline 11 & 200 & 28 & 7.1 \\
\hline 12 & 840 & 164 & 5.1 \\
\hline 13 & 648 & 62 & 10.5 \\
\hline 14 & 1280 & 320 & 4.0 \\
\hline 15 & 768 & 32 & 24.0 \\
\hline Median & 768 & 136 & 7.1 \\
\hline
\end{tabular}

ECP: eosinophilic cationic protein.

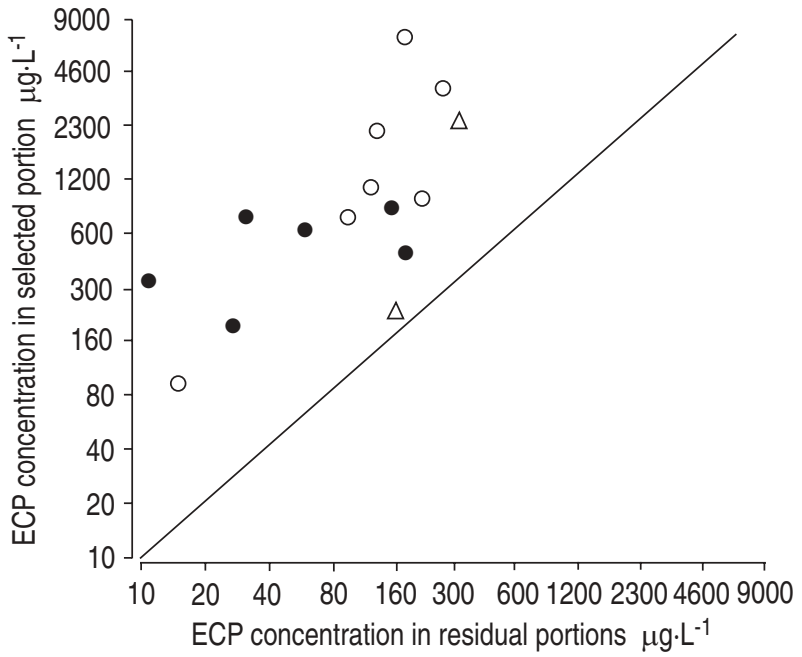

Fig. 1. - Concentrations of ECP $\left(\mu \mathrm{g} \cdot \mathrm{L}^{-1}\right)$ in the fluid phase, in selected and residual portions of expectorate. $\bullet$ : healthy subjects; $O$ : asthmatic subjects, where selection was by naked eye; $\Delta:$ asthmatic subjects where an inverted microscope was needed to select the sputum. In all subjects, the ECP concentration was greater in the selected portion than in the residual ( $\mathrm{p}<0.001$, groups comparison). The concentrations tended to be higher in asthmatics. 
The study was not designed to measure differences between healthy and asthmatic subjects. However, in the selected portions, asthmatics had a higher median (range) proportion of eosinophils, $1.3(0.4-72.1) \%$, than healthy subjects, $0.3(0.2-2.0) \%(\mathrm{p}<0.05)$. Asthmatics also tended to have higher ECP concentrations in the selected portion, $1040(96-6800) \mu \mathrm{g} \cdot \mathrm{L}^{-1}$, than healthy subjects, 560 (200-920) $\mu \mathrm{g} \cdot \mathrm{L}^{-1}(\mathrm{p}=0.09)$. The median ECP concentrations in the residual portion of asthmatics tended to be higher than in healthy subjects (176 vs 47) $\mu \mathrm{g} \cdot \mathrm{L}^{-1}(\mathrm{p}=$ $0.3)$.

\section{Discussion}

The induction of sputum by inhalation of an aerosol of hypertonic saline yields secretions from the lower respiratory tract (sputum) mixed with saliva. In this study, we showed that the selection of more viscid portions of the expectorate minimized contamination with squamous epithelial cells (saliva). This specimen contains two-thirds of the viable nonsquamous cells. Cytospins prepared from it were of better quality, making them easier to read. These selected portions usually contained a similar proportion of neutrophils, eosinophils and lymphocytes and much higher concentrations of the fluid-phase ECP. In these subjects, selection of uncontaminated sputum from the remainder of the expectorate generally did not distort the indices of airway inflammation. Whilst there was a loss of some cells, there was no selective loss. The characteristics of the cellular response and level of fluid-phase ECP is representative of lower respiratory secretions. Whilst this applies to normal subjects and treated asthmatics in this study, it may not do so in patients with other lung diseases or for other fluid-phase components.

The study was designed to investigate differences in the cell and fluid-phase content of selected portions of sputum from the remainder of the specimen which also includes saliva. We did not examine saliva uncontaminated by sputum, since this had already been reported in healthy and asthmatic subjects [5]. Saliva is composed mainly of squamous epithelial cells (99\%); it contains low levels of ECP $\left(2-90 \mathrm{ng} \cdot \mathrm{mL}^{-1}\right)$. Because squamous cells come from saliva and nonsquamous cells chiefly from the lower respiratory tract [18], we minimized the saliva expectorated by rinsing the mouth with water before each expectoration. Because nonsquamous cells might also originate from postnasal drip, we made this source unlikely by asking the subjects to blow their nose before expectoration. This assumption is supported by the high proportion of macrophages both in selected and residual portions. These cells are prominent in lower respiratory secretions and less prominent in nasal secretions.

The selected portion was contaminated with very little saliva, as indicated by the low squamous cell content of $1.2 \%$. The remaining portion was not only highly representative of saliva, as indicated by the squamous cell contents of $70 \%$ but the degree of salivary admixture varied considerably from specimen to specimen, as indicated by the varying weight of 2.2-127 times the weight of the selected portion. These results indicate that the measurement of inflammatory indices in sputum selected from the remainder of the expectorate should represent lower respiratory secretions uncontaminated by saliva, provided that information is not selectively lost or modified in the discarded residual portions.

Data could be missed or lost in the discarded expectorate in two ways. Firstly, the expectorate may appear homogeneous and like saliva but still contain lower respiratory secretions. There were two quite homogeneous samples among the 15 from asthmatic subjects in the present study. When these samples were examined under an inverted microscope, it was possible to identify and select out nonsquamous collections of cells presumed to be sputum. Due to the characteristic cellular content, the sputum from these two samples was not missed. Secondly, even in expectorates with sputum evident to the naked eye, some sputum may look like saliva and be left in the residual portion. That some sputum material was excluded is indicated by the presence of about one-third of the nonsquamous cells, of which one-third were macrophages in the residual portion. This loss of cells may influence the reproducibility of total cell counts in the selected portion. However, the selected portion has advantages in the viability of cells and the quality of cytospins and shows only questionable differences in the proportion of nonsquamous cells and much higher concentrations of fluid-phase ECP compared to the residual portion.

The selected portion contained a higher proportion of viable nonsquamous cells. The reason for this is unclear. Perhaps the mucus in which they are contained protects them from the treatment with DTT or salivary enzymes $[19,20]$. Cell viability is an important requirement for accurate cell identification. When the viability is greater than $50 \%$, the reproducibility of cell counts is better [21]. Higher viability may also be an advantage in studies involving immunological staining to determine the cell subtypes and activation markers [22, 23].

The selected portion produced a better quality of cell preparation on cytospins, particularly as a result of the reduced squamous cell content. Cytospins from three of the residual portions could not be counted because of poor quality. We have observed that when the squamous contamination was less than $20 \%$, the accuracy of differential cell counts was better, as indicated by high interand intraobserver reproducibility [21]. The counting of the cytospins is also quicker, especially when 1,000 or so cells need to be counted for more accurate differential counts of metachromatic cells and lymphocytes, which comprise small proportions of the total cells. Also, the small proportion of squamous cells provides a homogeneous population of cells for examination by flow cytometry [23].

The differential cell counts of eosinophils, neutrophils and lymphocytes were usually similar both in selected and residual portions, indicating that these cellular characteristics of the inflammatory process are identified appropriately in the selected portion. The proportion of neutrophils was higher than reported previously in sputum smears $[2,8]$, but was consistent with other reports using cytospins $[5,7,24]$. There was a slightly higher proportion (but not absolute number) of macrophages in the residual portions. A possible explanation for this is their easier recognition in the poorer quality cytospins of the residual portions, which contain an excessive amount of squamous epithelial cells [25], rather than a real increase in the proportion of these cells. 
The ECP concentrations were higher in all selected portions. One possible explanation for this observation is that ECP is sequestered into lower airway mucus secretions. It is also possible that the mucus affects the ECP measurement, falsely elevating it. This will need to be specifically investigated in the future by spiking studies. However, we believe that mucus is unlikely to influence the measurements because of the excellent correlations between ECP concentrations and eosinophil proportions (observed in this study) and between ECP concentrations and other eosinophil proteins and eosinophils in a further study [26]). Whilst there is evidence for a lack of significant loss of ECP in the residual portion, it is possible that other fluid-phase components may be lost; this requires further investigation.

We observed high concentrations of fluid-phase ECP (median 1,040 $\mu \mathrm{g} \cdot \mathrm{L}^{-1}$ ) in the selected portions of asthmatics. It is difficult to compare these concentrations with those reported in other studies because of differences in the method of expression and the denominator. The concentrations we observed seemed slightly higher than those recorded by VIRCHOw et al. [4], who examined concentrations of ECP in sputum of hospitalized asthmatics by rocking selected portions of spontaneous sputum with saline (mean \pm SEM, $878 \pm 1058 \mu \mathrm{g} \cdot \mathrm{L}^{-1} \mathrm{ECP} \cdot \mathrm{g}^{-1}$ sputum). The $\mathrm{ECP}$ concentrations in samples reported here were higher than those reported in bronchoalveolar lavage (BAL) in asthma [27, 28], and in sputum mixed with saliva in healthy [5] or asthmatic subjects [5, 29, 30]. In BAL in asthmatics, ÄDELROTH et al. [27] recorded values ranging $6.2 \pm 51 \mu \mathrm{g} \cdot \mathrm{L}^{-1}$. BousQueT et al. [28] did not detect ECP in 10 healthy subjects or 14 out of 38 asthmatics. In the asthmatics in whom ECP was detectable, the concentrations were $2.55 \pm 33.7 \mu \mathrm{g} \cdot \mathrm{L}^{-1}$. In the whole expectorated specimen of sputum plus saliva in healthy subjects and asthmatics, FAHY and co-workers [5] found ECP concentrations of 26.1 vs $142.6 \mu \mathrm{g} \cdot \mathrm{L}^{-1}$, respectively. Presumably, the lower values in BAL specimens are due to the dilution of lower respiratory tract secretions with normal saline. In sputum plus saliva, the lower values are probably due to contamination with saliva, which adds a variable unknown volume to the fluid coming from the lower airway [31]. In support of this, ClAMAN et al. [31] observed a negative correlation between squamous cell contamination and ECP concentration. The results suggest that the levels of fluid phase measurements will be more comparable if sputum is selected from saliva.

The present study was not performed to compare measurements in healthy and asthmatic subjects. The failure to distinguish these groups by ECP concentration may be due to the fact that most of the asthmatics were on regular treatment with inhaled steroid, had stable asthma and had low sputum eosinophil counts, or to the small number of healthy and asthmatic subjects. When a larger number of samples of induced sputum with a wide range in eosinophil counts was examined, fluid-phase ECP concentration in asthmatics (median (interquartile range), $\left.1,040(3,008) \mu \mathrm{g} \cdot \mathrm{L}^{-1}\right)$ were different from healthy subjects $288(338) \mu \mathrm{g} \cdot \mathrm{L}^{-1}$ or smokers with nonobstructive bronchitis $352(725) \mu \mathrm{g} \cdot \mathrm{L}^{-1}(\mathrm{p}<0.01)$ [26].

As a source of material to measure indices of lower airway inflammation, uncontaminated sputum selected from a mixed expectorate of sputum plus saliva has several advantages over the whole expectorate. It is almost free of squamous cells and is therefore essentially undiluted. Cells are in better condition and the concentrations of eosinophilic cationic protein are higher. In this study, the amount of sputum in the residual portion was generally sparse, so that discarding it did not seriously distort the results. Under other conceivable conditions, this technique might introduce larger errors, e.g. where sputum is not processed within $2 \mathrm{~h}$, is inhomogeneous with a large serous portion which mixes with saliva and a mucus part which resists mixing, and where these two parts differ in composition. Whether such inhomogeneities occur in practice remains to be established. However, if the results are generally applicable, the selection process should improve the standardization of the procedure, which is needed for the accurate interpretation and comparison of results. It should also improve the repeatability, responsiveness and validity of the measurements.

Acknowledgements: The authors wish to thank A. Girgis-Gabardo for processing the sputum and S. Evans for performing the ECP assays. They thank Pharmacia Diagnostics AB, Uppsala, Sweden for providing the ECP kits.

\section{References}

1. O'Byrne PM, Hargreave FE. Noninvasive monitoring of airway inflammation. Am J Respir Crit Care Med 1994; 150: S100-102.

2. Gibson PG, Girgis-Gabardo A, Morris MM, et al. Cellular characteristics of sputum from patients with asthma and chronic bronchitis. Thorax 1989; 44: 693-699.

3. Pin I, Gibson PG, Kolendowicz R, et al. Use of induced sputum cell counts to investigate airway inflammation in asthma. Thorax 1992; 47: 25-29.

4. Virchow JC Jr, Holscher U, Virchow C Sr. Sputum ECP levels correlate with parameters of airflow obstruction. Am Rev Respir Dis 1992; 146: 604-606.

5. Fahy JV, Liu J, Wong X Boushey HA. Cellular and biochemical analysis of induced sputum from asthmatic and healthy individuals. Am Rev Respir Dis 1993; 147: 1126-1131.

6. Maestrelli P, Calcagni PG, Saetta M, et al. Sputum eosinophilia after responses induced by isocyanate in sensitized subjects. Clin Exp Allergy 1994; 24: 29-34.

7. Popov T, Gottschalk R, Kolendowicz R, Dolovich J, Powers P, Hargreave FE. The evaluation of a cell dispersion method of sputum examination. Clin Exp Allergy 1994; 24: 778-783.

8. Iredale MJ, Wanklyn AR, Phillips IP, Krausz T, Ind PW. Noninvasive assessment of bronchial inflammation in asthma: no correlation between eosinophilia of induced sputum and bronchial responsiveness to inhaled hypertonic saline. Clin Exp Allergy 1994; 24: 940-945.

9. Dorland's Illustrated Medical Dictionary. Philadelphia, WB Saunders Co., 27th edn., 1988; p.1570.

10. Risse EK, Vooijs GP, van't Hof MA. Relationship between the cellular composition of sputum and the cytologic diagnosis of lung cancer. Acta Cytol 1987; 31: 170-176.

11. Murray PR, Washington JA. Microscopic and bacteriologic analysis of expectorated sputum. Mayo Clinic Proc 1975; 50: 339-344. 
12. Morris AJ, Tanner DC, Reller B. Rejection criteria for endotracheal aspirates from adults. J Clin Microbiol 1993; 31: 1027-1029.

13. Crapo RO, Morris AH, Gardner RM. Reference spirometric values using techniques and equipment that meets ATS recommendations. Am Rev Respir Dis 1981; 123: 659-694.

14. Juniper EF, Cockcroft DW, Hargreave FE. Histamine and methacholine inhalation tests: a laboratory tidal breathing protocol. Lund, Sweden, Astra Draco AB, 1994.

15. Efthimiadis A, Popov T, Kolendowicz, Dolovich J, Hargreave FE. Increasing the yield of sputum cells for examination. Am J Respir Crit Care Med 1994; 149: A949.

16. Norman GR, Streiner DL. In: Biostatistics: The Bare Essentials. Mosby Year Book Inc., 1994; pp. 202-210.

17. Altman DG. In: Practical Statistics for Medical Research. Chapman \& Hall, 1991; pp. 229-321.

18. Chodosh S. Examination of sputum cells. N Engl J Med 1970; 282: 854-858.

19. Tang CS, Kung ITM. Homogenization of sputum with dithiothreitol for early diagnosis of pulmonary malignancies. Acta Cytol 1993; 37: 689-693.

20. Hansel TT. The cardinal importance of sputum microscopy. Clin Exp Allergy 1994; 24: 695-697.

21. Efthimiadis A, Pizzichini MMM, Pizzichini E, et al. The influence of cell viability and squamous cell contamination on the reliability of sputum differential cell counts. Am J Respir Crit Care Med 1995; 151: A384.

22. Hansel TT, Braunstein C, Walker C, et al. Sputum eosinophils from asthmatics express ICAM- 1 and HLADR. Clin Exp Immunol 1991; 86: 271-277.

23. Kidney JC, Wong AG, Efthimiadis A, Morris MM, Sears MR, Dolovich J, Hargreave FE. Elevated B-cells in sputum of asthmatics: close correlation with eosinophils. Am J Respir Crit Care Med 1996; 153: 540-544.

24. Popov TA, Pizzichini MMM, Pizzichini E, et al. Some technical factors influencing the induction of sputum for cell analysis. Eur Respir J 1995; 8: 559-565.

25. Roby TJ, Swan GE, Schumann GB, Enkema Jr LC. Reliability of a quantitative interpretation of sputum cytology slides. Acta Cytol 1990; 34: 140-146.

26. Pizzichini E, Morris M, Efthimiadis A, et al. Indices of airway inflammation in induced sputum: Reproducibility and validity of cell and fluid phase measurements. Am J Respir Crit Care Med 1996; (in press).

27. Adelroth E, Johansson S, Linden M, Venge P. Inflammatory cells and eosinophilic activity in asthmatics investigated by bronchoalveolar lavage. Am Rev Respir Dis 1990; 142: 91-99.

28. Bousquet J, Chanez P, Lacoste JY, et al. Indirect evidence of bronchial inflammation assessed by titration of inflammatory mediators in BAL fluid of patients with asthma. J Allergy Clin Immunol 1991; 88: 649-660.

29. Fahy JV, Liu J, Wong H, Boushey HA. Analysis of cellular and biochemical constituents in induced sputum after allergen challenge: a method for studying allergic airway inflammation. J Allergy Clin Immunol 1994; 93: 1031-1039.

30. Fahy JV, Wong H, Liu J, Boushey HA. Comparison of samples collected by sputum induction and bronchoscopy from asthmatic and healthy subjects. Am J Respir Crit Care Med 1995; 152; 53-58.

31. Claman DM, Boushey HA, Liu J, Wong H, Fahy JV. Analysis of induced sputum to examine the effects of prednisone on airway inflammation in asthmatic subjects. J Allergy Clin Immunol 1994; 94: 861-869. 